\title{
Ciliate community in the oligotrophic Gulf of Aqaba, Red Sea
}

\author{
Monika Claessens ${ }^{1, *}$, Stephen A. Wickham ${ }^{1}$, Anton F. Post ${ }^{2}$, Michel Reuter ${ }^{3}$ \\ ${ }^{1}$ Department of Organismal Biology, University of Salzburg, Hellbrunner Strasse 34, 5020 Salzburg, Austria \\ ${ }^{2}$ The Interuniversity Institute for Marine Science, Coral Beach, PO Box 469, Eilat 88103, Israel \\ ${ }^{3}$ General Ecology and Limnology, University of Cologne, Weyertal 119, 50923 Cologne, Germany
}

\begin{abstract}
Ciliate data were gathered along a $600 \mathrm{~m}$ deepwater column in central waters of the Gulf of Aqaba, Israel. Samples were taken during winter mixing, the onset of stratification in spring and during summer stratification (2003 to 2005). The phytoplankton community strongly differed in these 3 periods, from highest abundances of eukaryotic algae during mixing, followed by a Synechococcus bloom right after the onset of stratification and a Prochlorococcus-dominated community in summer. Ciliate abundance and biomass were high compared to chlorophyll standing stock, with maximal values of 3534 cells l$^{-1}$ and $3554 \mathrm{ng} \mathrm{C}^{-1}$, respectively. Abundances were at times 5 -fold higher than those found in comparable studies on nutrient-poor pelagic systems and approached those observed in coastal waters. Ciliate carbon:chlorophyll ratios of up to 26 were astonishingly high, as compared to values of 2 to 5 normally observed. This indicates a high efficiency of the ciliates in utilizing the available food. The phytoplankton community in the Gulf is dominated by picocyanobacteria, and by repacking the algal prey into accessible particles, protozoans might be an important intermediate link in the pathway between phytoplankton and metazoan grazers. Oligotrichs and nanociliates contributed up to 98 and $88 \%$ of ciliate total abundance, respectively. Small oligotrich species appeared to be the superior competitors in this oligotrophic marine system, being able to utilize the dominant picoautotrophs efficiently.
\end{abstract}

KEY WORDS: Nanociliates - Nutrient limitation - Ocean · Oligotrichia - QPS · Strombidium · Strobilidium · Tintinnids

\section{INTRODUCTION}

The Gulf of Aqaba, a northern arm of the Red Sea, is characterized by nutrient-poor waters and low chlorophyll a (chl a usually $<0.8 \mu \mathrm{g} \mathrm{l}^{-1}$ ). Phytoplankton biomass is dominated by species $<8 \mu \mathrm{m}$ (primarily the cyanobacteria Synechococcus and Prochlorococcus), while algae in the range of 8 to $100 \mu \mathrm{m}$ contribute less than $10 \%$ of chl a (Lindell \& Post 1995, Yahel et al. 1998). A strong correlation between ciliates and chl a predicts that low phytoplankton biomass in nutrientpoor waters should be accompanied by low ciliate biomass (Dolan \& Marrasé 1995, Dolan et al. 1999, Pitta et al. 2001 and literature cited therein). Therefore we expected ciliate abundance and biomass in the Gulf of Aqaba to be rather low.
On the other hand, the phytoplankton community in the Gulf of Aqaba shows regular seasonal dynamics associated with changes in hydrographic conditions and changing nutrient concentrations (Lindell \& Post 1995). Eukaryotic algae are most important during winter mixing, while with the onset of stratification in April, a Synechococcus bloom develops which depletes the residual nutrients. Prochlorococcus is then the most abundant phytoplankter during summer stratification, the period of lowest nutrient concentrations (Lindell \& Post 1995). Grazing on phytoplankton in the Gulf of Aqaba and in the Red Sea in spring is clearly dominated by microzooplankton (Sommer et al. 2002), which appears to be a common trend in oligotrophic marine systems (Calbet \& Landry 1999). However, studies of ciliates in marine systems often focus 
on tintinnids (e.g. Krsinic 1982, Dolan et al. 2006), with relatively little information on aloricate ciliates, especially their taxonomic composition. Thus there is likely a major role for ciliate grazers in the Gulf of Aqaba, but one for which data on their diversity and abundance are lacking. Here we present the first detailed assessment of species richness in the ciliate community at large, from the smallest ciliates $(<10 \mu \mathrm{m})$ to the large tintinnids $(<400 \mu \mathrm{m})$, for the Gulf of Aqaba during 2003 to 2005 .

\section{MATERIALS AND METHODS}

Study site and sampling. Samples were taken at a regular sampling station $\left(\mathrm{Stn} A, 29^{\circ} 28^{\prime} \mathrm{N}, 34^{\circ} 55^{\prime} \mathrm{E}\right.$; Fig. 1) in the Gulf of Aqaba, Israel. Within a short distance from the coast, the Gulf has hydrographic conditions resembling those of the open ocean, with no discernible coastal effects on the nutrient regimes and plankton biology. The maximum depth in the Gulf is $1800 \mathrm{~m}$, and at Stn A the depth is $650 \mathrm{~m}$. There is an influx of warm surface waters from the Red Sea and an efflux of deep, more saline water across the Straits of Tiran, and the Gulf has warm $\left(20.7^{\circ} \mathrm{C}\right)$, deep waters (for more details see Lindell \& Post 1995). During winter, deep convective mixing may reach down to $600 \mathrm{~m}$ and deeper. As a consequence, nutrient-rich deep waters are injected into the surface layers. Nutrients become depleted with the onset of stratification in April.

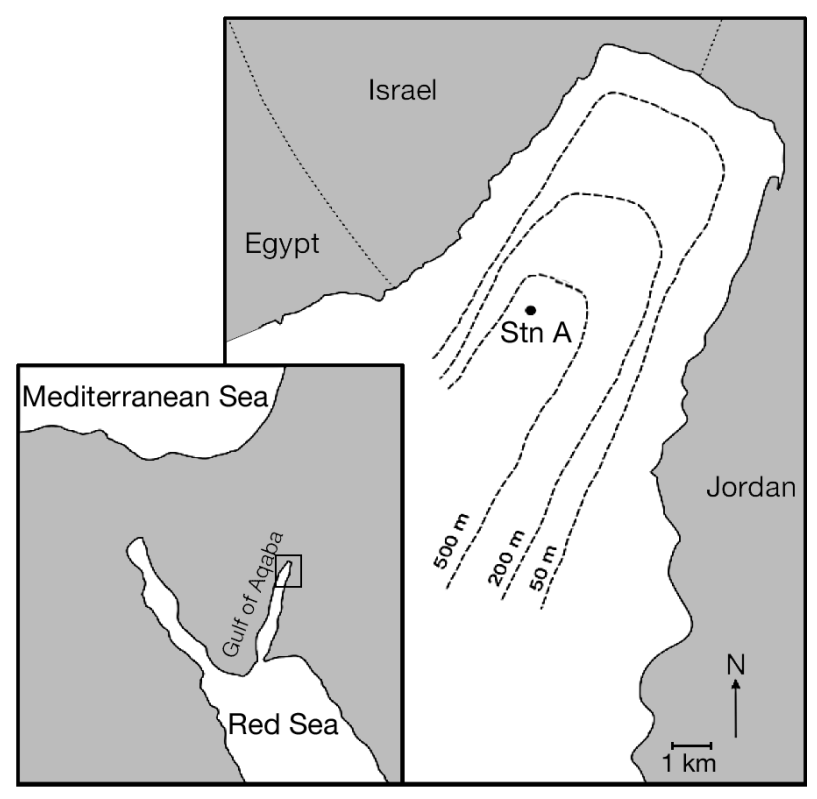

Fig. 1. Sampling region, the Gulf of Aqaba, Red Sea, showing the sampling station (Stn A). Bathymetry data are from Monismith et al. (2006)
Water samples were taken during winter mixing with high densities of eukaryotic algae (March) and during stratification with a Synechococcus bloom in spring (April) and a Prochlorococcus bloom in late summer (August/September). Sampling dates were 21 August and 9 September 2003, 21 March and 2 September 2004 and 23 March and 17 April 2005. Triplicate water samples for each depth and each sampled date were drawn from 121 Niskin bottles mounted on a CTD-Rosette from 5 different depths: surface, 80, 140, 350 and $600 \mathrm{~m}$. These depths represent the boundaries of the upper mixed layers, a typical depth for deep chlorophyll maximum and the deep non-mixed (during stratification) layers. We present averaged ciliate abundance and biomass data, which were calculated from the 3 replicates and from the replicate sampling dates for March and summer. The period after the onset of stratification in April was sampled once; here the averaged values were calculated with the 3 replicates from each depth. Vertical profile data for temperature, in vivo chl a fluorescence and phytoplankton abundance were collected. Lindell \& Post (1995) found a significant linear correlation between in vivo chl a fluorescence and chl a concentration after extraction in the Gulf of Aqaba. Thus chl a fluorescence was considered representative of extractable chl a concentrations. Phytoplankton samples were analyzed on a FACScan flow cytometer (Becton Dickenson); Prochlorococcus populations were only in part enumerated due to their generally low autofluorescence intensities. Flow cytometry was also applied to assess bacterial abundances. Bacteria were stained with SYBR Green I Nucleic Acid Gel Stain (Molecular Probes, S7563) following Marie et al. (2004). The cytometer was equipped with an Argon-ion laser (emitting light: $488 \mathrm{~nm}$ ). The cells side scatter (SSC), forward scatter (FSC), SYBR Green-induced green fluorescence (FL1), chlorophyll-induced red fluorescence (FL3) and phycoerythrin-induced orange fluorescence (FL2) were the measured parameters. Phytoplankton and bacteria data were provided by Amatzia Genin (The Interuniversity Institute for Marine Science, Eilat, Israel). Samples for ciliate identification and enumeration were fixed in Bouin's solution (5\% final concentration) and then settled in 11 graduated cylinders for $5 \mathrm{~d}$. For all sampled dates and depths, replicate samples were analyzed in terms of ciliate densities and taxonomic composition. The samples were then reduced to a volume of $100 \mathrm{ml}$ by siphoning off the upper $900 \mathrm{ml}$. Ciliates were enumerated and measured in length and width in settlement chambers according to the Utermöhl method. The counted volume was between 100 and $500 \mathrm{ml}$, depending on ciliate abundance with a detection limit of 2 cells $\mathrm{l}^{-1}$. Ciliates were counted as distinct morphotypes in the settlement chamber, and 
these morphotypes were taxonomically classified by microscopy after applying quantitative protagol stain (QPS), a silver staining method (Skibbe 1994). Mixotrophy of ciliates was identified with the QPS method. The QPS protocol was modified with respect to the agar embedding. After the embedding, the filters were left on a warm plate for at least $10 \mathrm{~min}$; slides were then transferred to $4^{\circ} \mathrm{C}$ for at least $10 \mathrm{~min}$. Preliminary tests showed that this modification tended to reduce the loss of larger species, especially tintinnids, from the filters. Ciliate taxonomy followed Lynn \& Small (2000), and ciliates were identified according to Kofoid \& Campbell (1929, 1939), Lynn \& Montagnes (1988), Lynn et al. (1988), Petz \& Foissner (1992), Lynn \& Gilron (1993), Montagnes \& Taylor (1994), Suzuki \& Song (2001), Agatha (2004), Agatha et al. (2005) and Skovgaard \& Legrand (2005). Ciliate biovolumes were calculated with appropriate geometric models and were translated into biomass; for aloricate species the

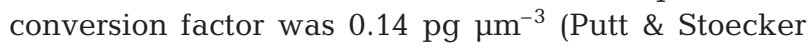
1989). For tintinnids the lorica volumes were transferred into ciliate biomass with the conversion factor

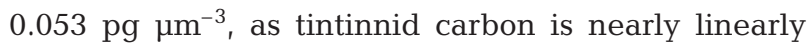
correlated with lorica volume (Verity \& Langdon 1984). The calculated ciliate carbon values (from conversion of biovolumes) were divided by the corresponding in vivo chlorophyll contents (same date and depth as ciliate samples) to determine ciliate carbon:chlorophyll ratios.

Statistical analysis. The abundance profile data were analyzed with regard to differences within the vertical distribution or differences between the different sampling dates with ANOVA and a post hoc test (Ryan-Einot-Gabriel-Welsch F). The test was made for abundance data only as abundance and biomass developed similarly. ANOVAs were carried out with the 3 replicates taken for each depth, treating the vertical distribution for each profile separately. The relationship between chlorophyll and ciliate abundance, and biomass was analyzed with Pearson's correlation coefficient.

\section{RESULTS}

\section{Hydrographic characteristics and chlorophyll}

The typical pattern in the Gulf of Aqaba, with stratification from spring to late summer, followed by deep mixing events in winter to early spring was reflected in the development of the temperature and chl a profiles (Fig. 2). A homogenous layer with temperatures ca. 25 to $26^{\circ} \mathrm{C}$ from the surface to $40 \mathrm{~m}$ and a deep chlorophyll maximum (DCM) at $80 \mathrm{~m}$ with highest chl $a$ concentration ca. $0.3 \mu \mathrm{g} \mathrm{l^{-1 }}$ was found during summer stratification (Fig. 2). The thermocline was between 40 and $100 \mathrm{~m}$, with a temperature gradient between 25 and $22^{\circ} \mathrm{C}$, that was followed by a deep cooler layer (20 to $21^{\circ} \mathrm{C}$ ). During winter mixing, the water column was mixed from the surface down to $600 \mathrm{~m}$, with homogenous temperatures $\left(21^{\circ} \mathrm{C}\right)$ and chl a distributions $\left(0.1\right.$ to $0.2 \mu \mathrm{g} \mathrm{l}^{-1}$ ) over the whole depth. Sea surface warming in spring caused the onset of stratification in April (Fig. 2) and homogenous chl a values throughout the surface mixed layer $\left(0.4 \mu \mathrm{g} \mathrm{l^{-1 }}\right.$; Fig. 2). $\mathrm{Chl}$ a was lowest in spring during mixing in the surface layer $\left(0.1 \mu \mathrm{g} \mathrm{l}^{-1}\right)$, and the highest chl a value was recorded in April $\left(0.4 \mu \mathrm{g} \mathrm{l}^{-1}\right)$.

\section{Phytoplankton and heterotrophic bacteria}

Relatively high numbers of small eukaryotic algae

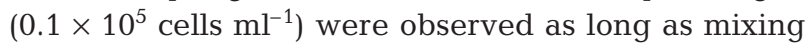
continued. Synechococcus abundances were in the same range as those of eukaryotic algae, while Prochlorococcus was not measurable during mixing $\left(<10^{3}\right.$ cells $\mathrm{ml}^{-1}$; Lindell \& Post 1995). Phytoplankton and bacteria $\left(0.5 \times 10^{6}\right.$ cells $\left.\mathrm{ml}^{-1}\right)$ were equally distributed over depth during the mixing period (Fig. 3). With the onset of stratification, nutrients became limiting for eukaryotic algae in the upper mixed layers and their density declined (Lindell \& Post 1995). Synechococcus abundance increased 1 order of magnitude $\left(1.1 \times 10^{5}\right.$ cells $\left.\mathrm{ml}^{-1}\right)$, but Prochlorococcus densities were still very low $\left(<10^{3}\right.$ cells $\left.\mathrm{ml}^{-1}\right)$. Abundances of Synechococcus and bacteria $\left(1.9 \times 10^{6}\right.$ cells $\left.\mathrm{ml}^{-1}\right)$ showed abundance maxima in the surface layer, while densities of phytoplankton and bacteria were reduced in the

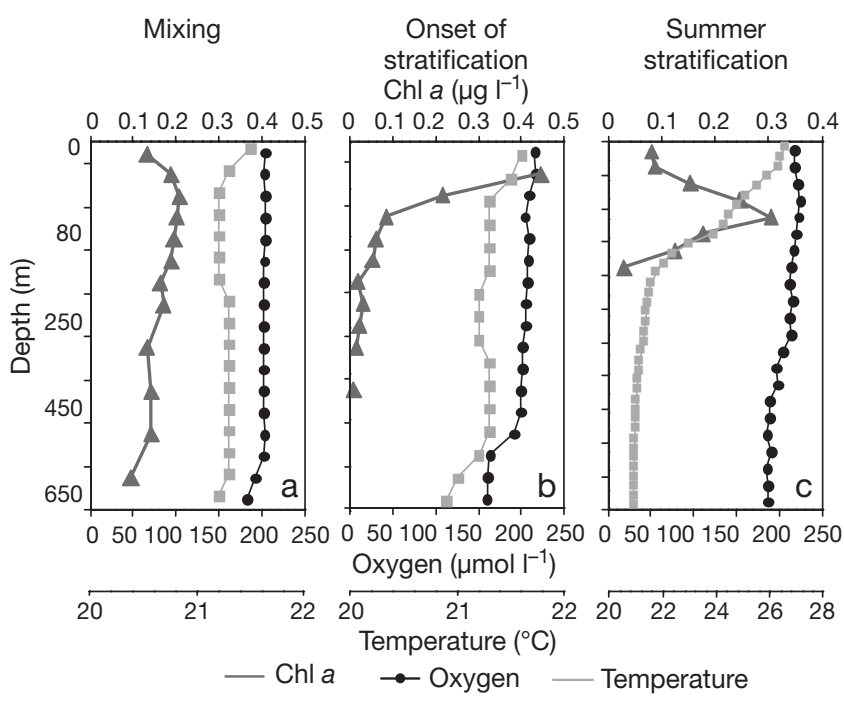

Fig. 2. Exemplary profiles of chlorophyll, oxygen and temperature. (a) Mixing (23.3.05), (b) onset of stratification (17.4.05) and (c) summer stratification (10.8.03) 


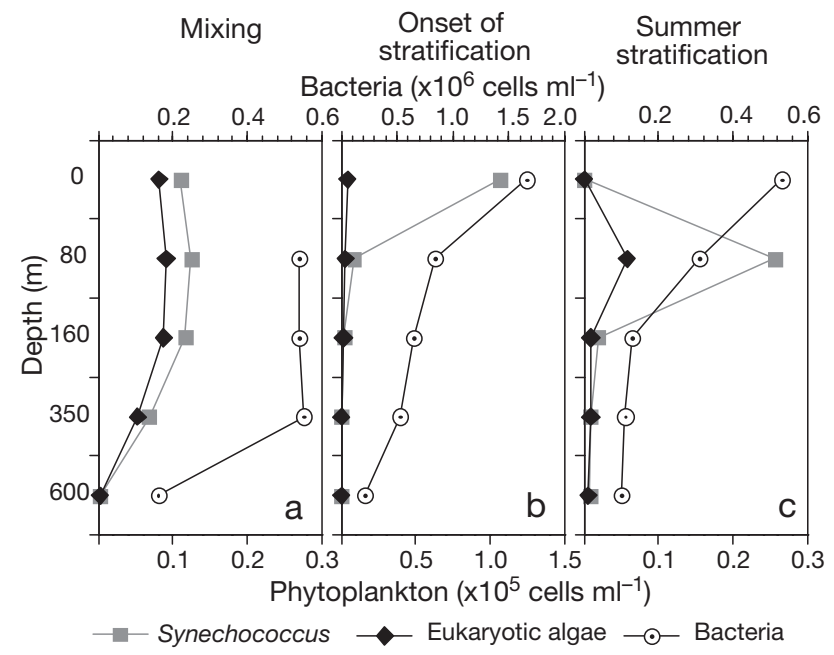

Fig. 3. Profiles of Synechococcus, eukaryotic algae and bacterial abundance. (a) Mixing (21.3.04), (b) onset of stratification (17.4.05) and (c) summer stratification (2.9.04). Data were provided by Amatzia Genin (The Interuniversity Institute for Marine Science, Eilat, Israel)

deeper layers (Fig. 3). After 4 mo of stable stratification, Prochlorococcus had replaced Synechococcus populations in late summer. Synechococcus dominated in August/September at abundances of $>10^{5} \mathrm{cells} \mathrm{ml}^{-1}$. Abundances of bacteria $\left(0.53 \times 10^{6}\right.$ cells ml $\left.{ }^{-1}\right)$ were in the same range as during mixing. Bacterial abundances were highest in the surface layer, while Synechococcus had a peak at $80 \mathrm{~m}$.

\section{Ciliate abundance and biomass}

Abundance and biomass of ciliate populations showed distinct seasonal differences (Fig. 4). The results of the ANOVA clearly reflected the mixing events in winter. No differences in the vertical abundance distribution were observed for March 2004 (0 to $600 \mathrm{~m}$ : 335 to $430 \pm 40$ to 157 [SD, here and elsewhere] cells $\mathrm{l}^{-1}$; 393 to $465 \pm 100$ to $390 \mathrm{ng} \mathrm{C} \mathrm{l}^{-1}$ ). In winter 2004/2005 mixing did not extend to $600 \mathrm{~m}$, and therefore the ciliate community at this depth was not connected to the upper mixed layer ciliates. Ciliate abundance and biomass in $600 \mathrm{~m}$ was $<3 \%$ of what was found in the upper $350 \mathrm{~m}$, a significant difference $(p<0.001)$. The ciliate community was clearly affected by the onset of stratification in April. Highest ciliate abundance and biomass was observed in the surface layer in April (Fig. $4 ; 3534 \pm 419$ cells l $^{-1} ; 3554 \pm 2305$ ng $\mathrm{C}^{-1}$ ), while ciliates declined in the deeper layers, and in 2 of the three $600 \mathrm{~m}$ replicates no ciliates were found $\left(2 \pm 3\right.$ cells $\left.\mathrm{l}^{-1} ; 10 \pm 17 \mathrm{ng} \mathrm{Cl}^{-1}\right)$. The abundance in the surface layer was significantly higher than the densities in the deeper layers $(\mathrm{p}<0.001 ; 80$ to $350 \mathrm{~m}$ : 345 to $151 \pm 44$ to 99 cells ${ }^{-1}$ ). Both abundance and biomass declined strongly along the vertical profile during summer stratification, with highest averaged

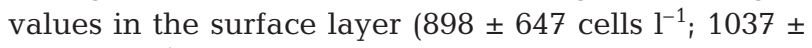
$538 \mathrm{ng} \mathrm{C}^{-1}$ ) and lowest values in the $600 \mathrm{~m}$ samples (11 \pm 4 cells $\mathrm{l}^{-1} ; 10 \pm 6 \mathrm{ng} \mathrm{C}^{-1}$ ). Abundance in the surface

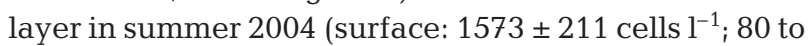
$350 \mathrm{~m}: 510$ to $13 \pm 23$ to 4 cells $\mathrm{l}^{-1}$ ) was higher than that in the summer 2003 profiles (302 to $480 \pm 20$ to 50 cells $\mathrm{l}^{-1}$ ), but densities at the other depth were in the same range (622 to $18 \pm 217$ to 0 cells $1^{-1}$ ). In summer 2003 and 2004 ciliates were most important in the surface layer, while they were rarely found in the deep layers $(\mathrm{p}=$ 0.001 and $p<0.001$, respectively). We found a significant correlation between chlorophyll and ciliate abundance and biomass over all seasons ( $p=0.002, r=0.81$; $p=0.003, r=0.77$, respectively), but the detailed correlation analysis showed relationships between chl $a$ and ciliate abundance and biomass only for April ( $p=0.002$, $r=0.998 ; p=0.003, r=0.997)$. In summer, the deep chlorophyll maximum at $80 \mathrm{~m}$ was not accompanied by a peak in ciliate biomass. $\mathrm{Chl} a$ in the Gulf of Aqaba represented the amount of edible algae for ciliates, as phytoplankton was mostly dominated by picophytoplankton, which at least in terms of size was an appropriate food source. Thus, the ciliate carbon:chlorophyll ratio was calculated to assess the potential food concentration and to evaluate the utilization of algae by the ciliates. Despite the nutrient-poor status of the Gulf, the ciliate carbon:chlorophyll ratio was between 2 and 26 . This ratio was calculated for the surface to 140 m layers, as in the deeper layers no chlorophyll data were available. The ciliate carbon:chlorophyll ratios were comparable in March and April (2 to 8 and 3 to 6, respectively) but were clearly higher in summer (13 to 26).

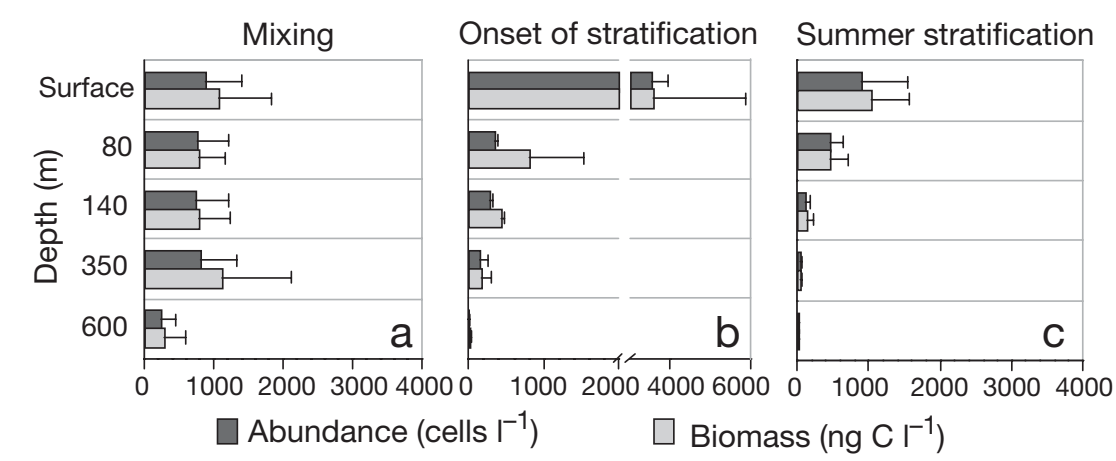

Fig. 4. Profiles of average (+SD) ciliate abundance and biomass during (a) winter mixing, (b) onset of stratification and (c) summer stratification. Averaged values and error bars were calculated from the 3 replicates of each depth and from the replicate sampling dates (except for April) 
Taxonomic composition and sizedistribution

Ciliates were counted as morphotypes, which in most cases allowed identification to genus. One hundred twenty-three morphotypes were distinguished along with 45 aloricate Choreotrichia and Oligotrichia (henceforth grouped as naked oligotrich ciliates), 41 Tintinnida, 11 Prostomatea and 13 Litostomatea. Thirteen morphotypes belonged to the group named 'Others', which were ciliates observed only once and those that could not be classified in one of the ciliate groups. Due to the high species richness, not all ciliates were determined to species level, as not enough specimens were found to assess sufficient morphological details.

The naked oligotrich ciliates were the most important group with respect to abundance and biomass in all seasons and all depths (Fig. 5). The highest abundance and biomass of aloricate oligotrichs were observed in April in the surface layer (3450 cells $\mathrm{l}^{-1}$; $3522 \mathrm{ng} \mathrm{C}^{-1}$ ). The small Strombidium epidemum in particular was found in high densities in this period and reached 2404 cells $1^{-1}$ near the surface. The pro-

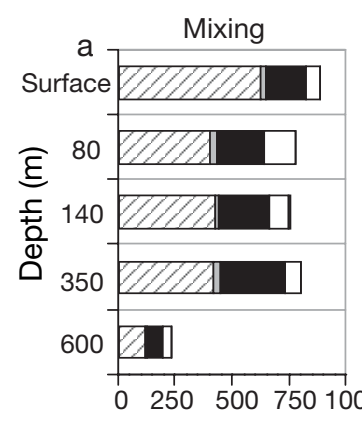

Onset of stratification Summer stratification
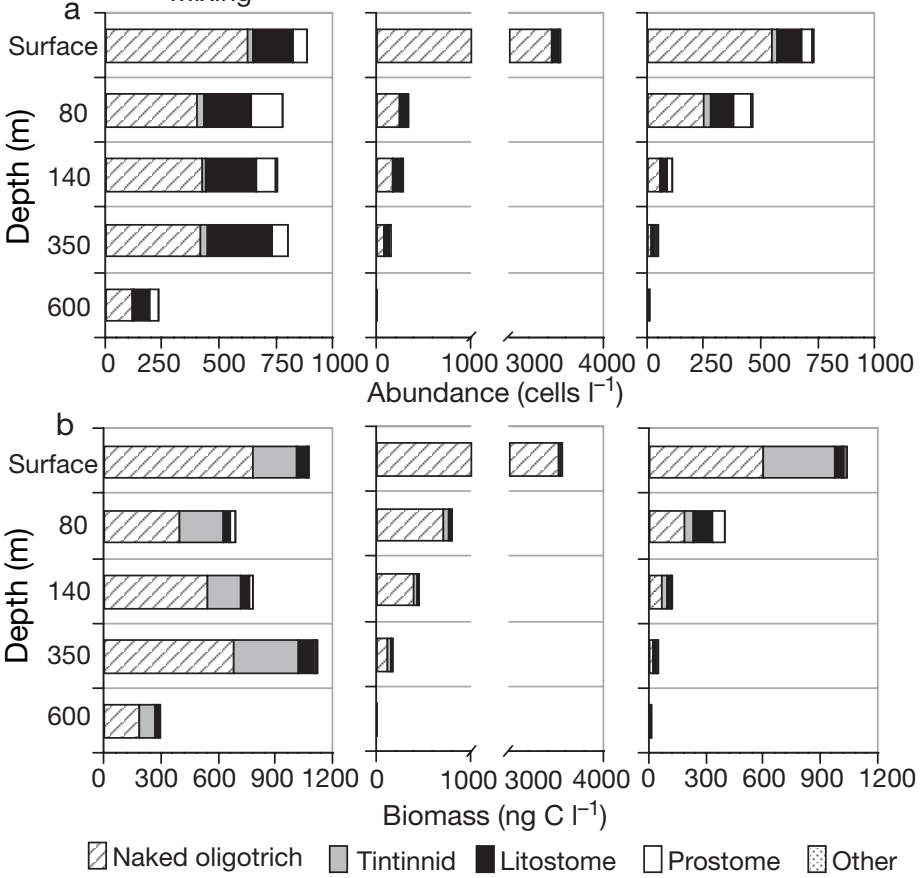

Fig. 5. Profiles of average (a) ciliate abundance and (b) biomass for the taxonomic groups naked oligotrichs, tintinnids, litostomes, prostomes and 'others'. Averaged values and error bars were calculated from the 3 replicates of each depth and from the replicate sampling dates (except for April) portion of the naked oligotrichs in the total abundance and biomass was between 43 and $98 \%$ and 10 and $99 \%$, respectively. Regularly found species were Pelagostrobilidium sp., Strobilidium multinucleatum, Leegardiella sol (with 3 macronuclei instead of the usual 2), Leegardiella ovalis, Strombidium dalum, Strombidium epidemum, Tontonia cornuta and Tontonia gracillima (Table 1). The second most abundant group were the litostomes (Fig. 5). In terms of biomass, tintinnids contributed more than the Litostomatea, despite their low numbers. Litostomes increased their proportion of total abundance especially during mixing in March, from the surface to $350 \mathrm{~m}$ (Fig. 5). Mixotrophy is an alternative trophic mode, which might affect competition and niche overlap (e.g. Dolan 2000, Pitta \& Giannakourou 2000, Pitta et al. 2001). Three mixotrophic species, Pseudotontonia cornuta and 2 unknown Strombidium species were found that made up maximally $14 \%$ of total ciliate abundance.

The ciliate community was divided into 3 size classes: small species $(\leq 20 \mu \mathrm{m}$; nanociliates; 16 morphotypes), medium-sized species (20 to $50 \mu \mathrm{m}_{i} 66$ morphotypes) and large species $(\geq 50 \mu \mathrm{m} ; 41$ morphotypes). The nanociliates were the dominant group in terms of abundance in all seasons and at all depths (maximum value: 2814 cells $^{-1}$ in April; Fig. 6). They contributed up to 88\% of total abundance and up to $63 \%$ of total biomass. The small species were mostly represented by oligotrich species; most important numerically was Strombidium epidemum and the litostome Askenasia sp. The mediumsized species were the second most important group with regard to abundance but contributed the highest proportion to total biomass during summer stratification

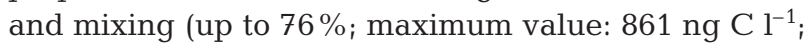
$0 \mathrm{~m}$ in April; Fig. 6). This group was represented by e.g. Tontonia gracillima, Strobilidium multinucleatum, 
Table 1. Ciliate species found in the Gulf of Aqaba, divided into Tintinnida, Choreotrichida, Oligotrichia, Litostomes and Prostomes. The group 'others' is not shown. Commonly found species represent the ciliates found in all seasons, and for which average biovolume are given $\left(\times 10^{3} \mu^{3} \mathrm{l}^{-1}\right)$. 'Oligotrichs 1 to $5^{\prime}$ could not be determined in detail as they were only found in the Utermöhl samples but not on the quantitative protagol stain (QPS) slides

\begin{tabular}{|c|c|c|c|c|c|}
\hline Tintinnida & Biovolume & Choreotrichida & Biovolume & Oligotrichia & Biovolume \\
\hline \multirow{2}{*}{\multicolumn{2}{|c|}{$\begin{array}{l}\text { Acanthostomella minutissima } \\
\text { Acanthostomella obtusa }\end{array}$}} & \multicolumn{4}{|c|}{ - Oligotrichs 1 to 5} \\
\hline & & Leegardiella ovalis & 9 & Askenasia sp. & 0.2 \\
\hline Amphorides quadrilineata & \multirow[t]{6}{*}{8} & Leegardiella sol & 9 & Pseudotontonia cornuta & 15 \\
\hline Codonella galea & & Leegardiella sp. 2 & & Spirotontonia grandis & 515 \\
\hline Codonella minor & & Lohmaniella oviformis & 2 & Strombidium bilobum & 5 \\
\hline Codonellopsis sp. & & Lohmaniella sp. 2 & & Strombidium choronatum & \\
\hline Cymatocylis sp. 1 & & Pelagostrobilidium sp. & 8 & Strombidium conicum & \\
\hline Cymatocylis sp. 2 & & Strobilidium sp. 6 & & Strombidium constrictum & 20 \\
\hline Dadayiella ganymedes & \multirow[t]{24}{*}{4} & Strobilidium sp. 7 & & Strombidium dalum & 0.6 \\
\hline Dictyocysta spinosa & & Strobilidium multinucleatum & 17 & Strombidium emergens & \\
\hline Eutintinnus fraknoi & & Strobilidium spiralis & 17 & Strombidium epidemum & 0.3 \\
\hline Eutintinnus lusus-undae & & Strobilidium neptuni & 17 & Strombidium sp. 1 to 7 & \\
\hline Eutintinnus sp. 1 to 3 & & \multicolumn{2}{|l|}{ Strombidinopsis acuminatum } & Strombidium tressum & \\
\hline Favella sp. 2 & & Strombidinopsis sp. & 20 & Tontonia caudata & \\
\hline Favella sp. 3 & & & & Tontonia cornuta & 25 \\
\hline Laackmanniella naviculaefera & & & & Tontonia gracillima & 3 \\
\hline Metacylis sp. & & & & Tontonia sp. & \\
\hline Nolaclusilis sp. & & & & & \\
\hline $\begin{array}{l}\text { Nolaclusilis sp. } 2 \\
\text { Ormosella bresslaui }\end{array}$ & & Litostomes & Biovolume & Prostomes & Biovolume \\
\hline Parafavella sp. & & Apsiktrata sp. & 1.2 & Balanion sp. & \\
\hline Parundella lohmanni & & Lacrymaria sp. & & Dissothigma sp. & \\
\hline Poroecus curtus & & Litostome 1 to 6 & & Prostome 1 to 6 & \\
\hline Protorhabdonella praetenius & & Mesodinium sp. & & Urotricha sp. & 2 \\
\hline Protorhabdonella sp. & & Mesodinium sp. 2 & & Urotricha sp. 2 & \\
\hline Rhabdonella sp. 2 & & & & & \\
\hline Salpingella sp. 2 to 7 & & & & & \\
\hline Steenstrupiella sp. & & & & & \\
\hline Tintinnid 1 to 4 & & & & & \\
\hline Undella sp. & & & & & \\
\hline Undella sp. 2 & & & & & \\
\hline Xystonella sp. & & & & & \\
\hline Xystonella treforti & & & & & \\
\hline
\end{tabular}

Strombidium emergens, Leegardiella sol, Leegardiella ovalis and some small tintinnids, such as Dictyocysta spinosa and Acanthostomella minutissima. Though numerically the least important size class, the large ciliates dominated the ciliate biomass in April in the upper layer (2530 $\mathrm{ng} \mathrm{Cl}^{-1}$ ). Mainly tintinnid species belonged to this group, such as Dadayiella ganymedes, Amphorides quadrilineata, Eutintinnus fraknoi and Xystonella treforti. Besides the tintinnids, Oligotrichia-e.g. Spirotontonia grandis and Tontonia cornuta-were among the large species.

Two morphotypes could not be identified to species level although sufficient morphological details were available, indicating they might be new species. The first was determined to belong to the genus Leegardiella (S. Agatha pers. comm.): $23 \mu \mathrm{m}$ diameter; 19 membranelles in the adoral poly- kinetid zone (APZ); crescent-shaped macronucleus and 1 row of somatic kineties as for Leegardiella ovalis but probably additional somatic kineties (Fig. 7). The second morphotype was identified as Pelagostrobilidium sp. (S. Agatha pers. comm.): $24 \mu \mathrm{m}$ diameter; 26 membranelles (APZ); horseshoe-shaped macronucleus and, most importantly, 6 rows of somatic kineties as opposed to 5 in other species (Fig. 8).

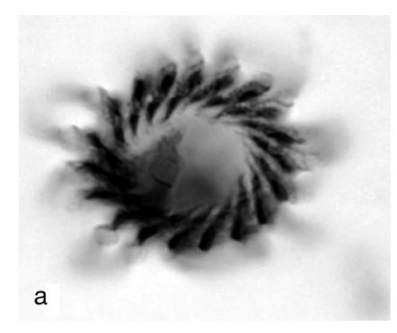

Fig. 7. Leegardiella sp. Morphological details showing (a) the oral region with membranelles, (b) crescent-shaped macronucleus and (c) somatic kineties (arrow), the bend of kineties that is characteristic for L. ovalis 


\section{DISCUSSION}

Despite the oligotrophic status of the Gulf of Aqaba, ciliate density and biomass were unexpectedly high, not only during nutrient-replete conditions in spring, but also in summer, when nutrients were strongly depleted (Table 2; Lindell \& Post 1995). The ciliate community was dominated by small oligotrich species, which efficiently used the available food sources and appeared to be the superior competitors.

\section{Ciliate abundance, biomass and community structure}

Ciliate abundance and biomass in the Gulf of Aqaba were high compared to the low chl a concentrations (Table 2). Comparing our ciliate data with literature was not simple, as sometimes no data to evaluate the trophic status were given. Though our sampling station was rather near to the coast, the conditions in terms of chlorophyll and nutrients were characteristic of the oligo- to ultraoligotrophic open waters (Lindell \& Post 1995). The trophic status of the eastern Mediterranean is comparable with the Red Sea. However, ciliate densities in spring in the eastern Mediterranean were lower than for the Gulf of Aqaba in March (300 to 545 cells $^{-1}$ compared to 884 cells l $^{-1}$ ), while biomass was comparable (Pitta \& Giannakourou 2000), stressing the importance of small species in the Gulf. The densities in the Gulf were up to 5-fold higher than abundances in other comparable studies in nutrientpoor systems (Revelante \& Gilmartin 1990, James \& Hall 1995, Leakey et al. 1996, Pitta et al. 2001). Even when the extremely high ciliate densities in April were not considered, the range of maximum abundances

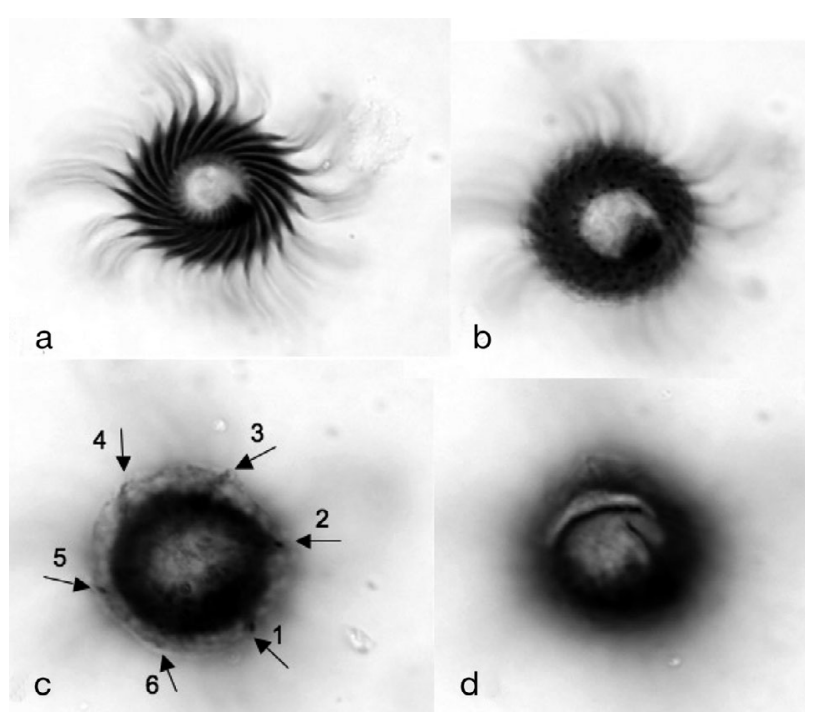

Fig. 8. Pelagostrobilidium sp. Morphological details showing (a) the oral region, (b) the horseshoe-shaped macronucleus, (c) rows (arrows) 1 to 6 of somatic kineties and (d) the pattern of the somatic kineties no. 1 and 6 at the posterior end of the cell

was 300 to 1600 cells $^{-1}$. Comparable maximum abundances were found in coastal waters or in more productive open ocean systems (Stoecker et al. 1989, James \& Hall 1995, Leakey et al. 1996) (Table 2). The high abundance and biomass data are supported by the ciliate carbon:chl a ratio ( $\mathrm{C}: \mathrm{chl}$ a). Across systems a rather constant ratio of $3 \mathrm{mg}$ ciliate carbon to $1 \mathrm{mg}$ chlorophyll is observed (Dolan \& Marrasé 1995, Dolan et al. 1999). For the Gulf of Aqaba the lowest ratios in March and April (2 and 3, respectively) reflected this typical value, but the maximal ratios were clearly

Table 2. Ciliate abundance and chlorophyll data for some oceanic and coastal environments. Table modified from Strom et al. (1993)

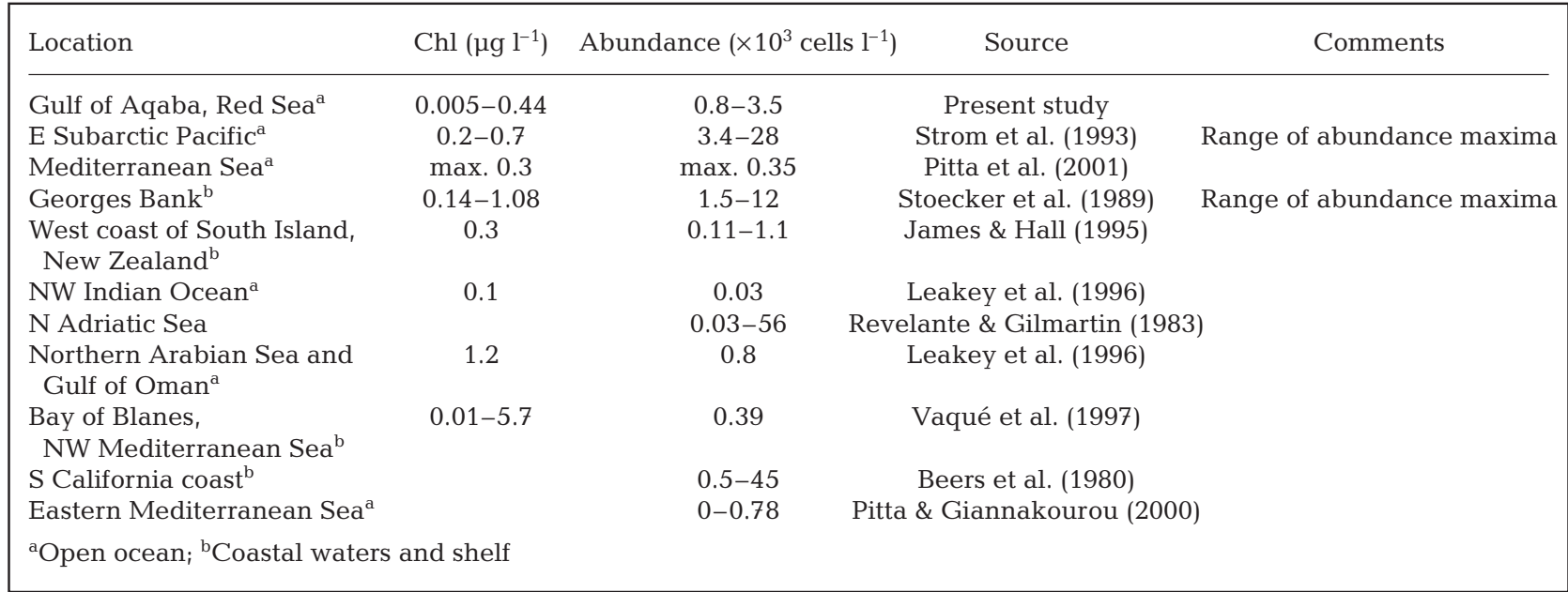


higher in all seasons (March: 6; April: 8; summer: 26) showing clearly higher ciliate biomasses per unit chl $a$. The ratio between ciliate $\mathrm{C}$ and chlorophyll was 0.8 to 8.8 times higher than we had expected with respect to the typical ratio of 3 (Dolan \& Marrasé 1995, Dolan et al. 1999). This suggests to some extent that the ciliate community is much more efficient in utilizing its food sources in all seasons. Alternative food sources could be heterotrophic bacteria and heterotrophic nanoflagellates (data not shown, but represent our own data). Flagellate abundance was very low and was dominated by autotrophs (flagellates $<500 \mathrm{cells} \mathrm{ml}^{-1}$ ). The highest abundance of heterotrophic bacteria was $2 \times$ $10^{6} \mathrm{cells} \mathrm{ml}^{-1}$, but only during the peak after the onset of stratification, and abundances were clearly lower in summer and during mixing $\left(5 \times 10^{5} \mathrm{cells}^{-1}\right)^{-1}$. Thus flagellates and bacteria were unlikely candidates to support the observed ciliate densities. Although, with the present data, we cannot evaluate the grade of topdown control of flagellates due to ciliate grazing.

Mixotrophy can be an alternative trophic mode, which might affect competition and niche overlap (e.g. Dolan 2000, Pitta \& Giannakourou 2000, Pitta et al. 2001). We found only 3 mixotrophic species that made up maximally $14 \%$ of abundance. This is clearly different from many other marine systems, where mixotrophic ciliates make up a substantial proportion of total abundance (e.g. Stoecker et al. 1989, Dolan et al. 1999, Pitta et al. 2001). This supports the hypothesis that the ciliates in the Gulf of Aqaba where highly efficient in utilizing the available food, so that mixotrophy gave no competitive advantage. Picocyanobacteria were the most important algal group in terms of abundance and, at least in spring and summer, in terms of biomass as well (Lindell \& Post 1995; Fig. 3). Picocyanobacteria are below the size range that can be grazed by most metazooplankton (Berggreen et al. 1988, Hansen et al. 1994). Moreover, picocyanobacteria lack polyunsaturated fatty acids (PUFAs) and sterols, both of which are essential for metazooplankton and can be synthesized by ciliates (Klein Breteler et al. 1999, Martin-Creuzburg et al. 2005, Bec et al. 2006). Therefore protozoans might be important intermediate links in the pathway between phytoplankton and metazoan grazers by repackaging the algal prey into accessible particles. The high ciliate carbon: chlorophyll ratios suggest that the ciliates were able to utilize a very large proportion of the phytoplankton community, which is not always observed in comparable marine systems (James \& Hall 1995). The connection between ciliates and picophytoplankton in the Gulf appeared to be high, as ciliates strongly reacted to increased densities of cyanobacteria, e.g. in April. Although the coupling between picophytoplankton and protozoa is tight, this link itself is loosely con- nected to the food web involving larger organisms (Reckermann \& Veldhuis 1997). Thus, the degree of top-down control for the ciliate community can be low but was not, however, evaluated in the present study. This might explain the unexpected high ciliate abundance, which is not found in other marine systems, although the dominance of Synechococcus and Prochlorococcus is regularly observed in oligotrophic marine systems (Partensky et al. 1999).

Previous studies have often focused on the larger tintinnids (e.g. Dolan 2000; Dolan et al. 2006), as the taxonomic determination of aloricate ciliates is much more difficult and time intensive. However, the remarkably high species richness in the Gulf of Aqaba includes new aloricate morphotypes, and potentially these morphotypes are new species. Therefore, it is hard to assess whether species richness in other systems might be comparably high, but overlooked, or whether endemic species in the Gulf of Aqaba contributed to the diversity. Some of the ciliate species found in the Gulf were regularly found in other marine systems (Table 1); especially within the tintinnids, many common species were found, e.g. Codonella galea, Eutintinnus fraknoi, E. lusus-undae, Dadayiella ganymedes or Xystonella treforti (e.g. Krsinic 1982, Dolan \& Marrasé 1995, Dolan 2000, Pitta et al. 2001, Dolan et al. 2006). The naked oligotrichs and nanociliates in the Gulf of Aqaba contributed up to 98 and $88 \%$ of total abundance and up to 99 and $63 \%$ of total biomass, respectively, emphasizing their important position in this system. This dominance was confirmed in several studies, where the aloricate oligotrichs contributed up to $70 \%$ of the total community, and the small ciliates were the dominant size class (James \& Hall 1995, Leakey et al. 1996, Pitta \& Giannakourou 2000). The small oligotrich species seemed to be superior competitors in the oligotrophic ocean, being able to utilize the dominant picoautotrophs as well as the larger eukaryotic algae efficiently. Strombidium epidemum in particular increased in numbers during the Synechococcus bloom in April, indicating a kind of specialization combined with the potential for rapid growth. Litostome ciliates became more important during the mixing period, suggesting that they were better competitors in the presence of higher densities of eukaryotic algae, and that they were less efficient at exploiting Synechococcus and Prochlorococcus (Fig. 5). The importance of the small $S$. epidemum reflected the general importance of the nanociliates in the oligotrophic open ocean (James \& Hall 1995, Pitta et al. 2001). The shortage at the resource level caused a shift in the system to a food web dominated by small organisms. This has previously been shown for autotrophs (Pitta \& Giannakourou 2000), but the present study shows this pattern to be also true for the 
autotrophs' main predators, the ciliates. The planktonic food web in the oligotrophic ocean is dominated by the microbial loop (Sanders et al. 1992, Sommer et al. 2002). In the Gulf of Aqaba, this dominance leads to a diverse and abundant ciliate community dominated by small, efficiently growing oligotrichs.

Acknowledgements. The work was funded by the Deutsche Forschungsgemeinschaft (DFG; grant WI 1623/3 to S. A. Wickham) and by the Germany-Israel Foundation (grant \#I732-54_8_2002) to A. F. Post. We are thankful to I. Ayalon and A. Genin for providing phytoplankton and bacterial abundances. We thank S. Agatha for helping us with the determination of some difficult ciliate species. We are grateful to D. Golan, A. Pitt and C. Lorenz for their assistance and organization. We thank M. Prast and J. Turner for comments.

\section{LITERATURE CITED}

Agatha S (2004) New observations on the tontoniid ciliate Spirotontonia grandis (Suzuki and Han, 2000) Agatha 2004 (Ciliophora, Oligotrichida, Tontoniidae); comparison with the similar Laboea strobila. Eur J Protistol 40: 295-301

Agatha S, Strüder-Kypke MC, Beran A, Lynn DH (2005) Pelagostrobilidium neptuni (Montagnes and Taylor, 1994) and Strombidium biamatum nov. spec. (Ciliophora, Oligotrichea): phylogenetic position inferred from morphology, ontogenisis, and gene sequence data. Eur J Protistol 41:65-83

Bec A, Martin-Creuzburg D, von Elert E (2006) Trophic upgrading of autotrophic picoplankton by the heterotrophic nanoflagellate Paraphysomonas sp. Limnol Oceanogr 51:1699-1707

> Beers JR, Reid FMH, Stewart GL (1980) Microzooplankton population structure in Southern California nearshore waters in late spring. Mar Biol (Berl) 60:209-226

Berggreen U, Hansen B, Kiørboe T (1988) Food spectra, ingestion and growth of the copepod Arcatia tonsa during development: implications for determination of copepod production. Mar Biol (Berl) 99:341-352

Calbet A, Landry MR (1999) Mesozooplankton influences on the microbial food web: direct and indirect trophic interactions in the oligotrophic open ocean. Limnol Oceanogr 44:1370-1380

Dolan JR (2000) Tintinnid ciliate diversity in the Mediterranean Sea: longitudinal patterns related to water column structure in late spring-early summer. Aquat Microb Ecol 22:69-78

Dolan JR, Marrasé C (1995) Planktonic ciliate distribution relative to a deep chlorophyll maximum: Catalan Sea, N.W. Mediterranean, June 1993. Deep-Sea Res I 42: 1965-1987

Dolan JR, Vidussi F, Claustre H (1999) Planktonic ciliates in the Mediterranean Sea: longitudinal trends. Deep-Sea Res I 46:2025-2039

Dolan J, Jacquet S, Torreton JP (2006) Comparing taxonomic and morphological biodiversity of tintinnids (planktonic ciliates) of New Caledonia. Limnol Oceanogr 51:950-958

Hansen B, Bjõrnsen PK, Hansen PJ (1994) The size ratio between planktonic predators and their prey. Limnol Oceanogr 39:395-403

James MR, Hall JA (1995) Planktonic ciliated protozoa: their distribution and relationship to environmental variables in a marine coastal ecosystem. J Plankton Res 17:659-683

Klein Breteler WCM, Schogt N, Baas M, Schouten S, Kraay GW (1999) Trophic upgrading of food quality by protozoans enhancing copepod growth: role of essential lipids. Mar Biol (Berl) 135:191-198

Kofoid CA, Campbell AS (1929) A conspectus on the marine and freshwater ciliata belonging to the suborder Tintinnoinea, with descriptions of new species principally from the Agassiz expedition to the eastern tropical Pacific. Univ California Pub Zool 34:1-403

Kofoid CA, Campbell AS (1939) Reports on the scientific results of the expedition to the Eastern tropical Pacific 1904-1905. Bull Mus Comp Zool 84:1-473

Krsinic F (1982) On vertical distributions of tintinnines (Ciliata, Oligotrichida, Tintinna) in the open waters of the South Adriatic. Mar Biol 68:83-90

> Leakey RJG, Burkill PH, Sleigh MA (1996) Planktonic ciliates in the northwestern Indian Ocean: their abundance and biomass in waters of contrasting productivity. J Plankton Res 18:1063-1071

Lindell D, Post AF (1995) Ultraphytoplankton succession is triggered by deep winter mixing in the Gulf of Aqaba (Eilat), Red Sea. Limnol Oceanogr 40:1130-1141

Lynn DH, Gilron GL (1993) Strombidiid ciliates from coastal waters near Kingston Harbor, Jamaica (Ciliophora, Oligotrichia, Strombididae). J Mar Biol Assoc UK 73:47-65

Lynn DH, Montagnes DJS (1988) Taxonomic descriptions of some conspicuous species of strobilidiine ciliates (Ciliophora: Choreotrichida) from the isles of shoals, Gulf of Maine. J Mar Biol Assoc UK 68:639-658

Lynn DH, Small EB (2000) Phylum Ciliophora Doflein 1901. In: Lee JJ, Leedale GF, Bradbury P (eds) An illustrated guide to the protozoa, Vol 1, 2nd edn. Society of Protozoologists, Lawrence, KS

Lynn DH, Montagnes DJS, Small EB (1988) Taxonomic description of some conspicuous species in the family Strombidiidae (Ciliophora: Oligotrichida) from the isles of shoals, Gulf of Main. J Mar Biol Assoc UK 68:259-276

Marie D, Simon N, Vaulot D (2004) Phytoplankton cell counting by flow cytometry. In: Andersen R (ed) Algal culturing techniques. Academic Press, Burlington, MA, p 253-267

Martin-Creuzburg D, Bec A, Von Elert E (2005) Trophic upgrading of picocyanobacterial carbon by ciliates for nutrition of Daphnia magna. Aquat Microb Ecol 41: $271-280$

Monismith SG, Genin A, Reidenbach MA, Yahel G, Koseff JR (2006) Thermally driven exchanges between a coral reef and the adjoining ocean. J Phys Oceanogr 36:1332-1347

> Montagnes DJS, Taylor FJR (1994) The salient features of five marine ciliates in the class Spirotrichea (Oligotrichia), with notes on their culturing and behavior. J Eukaryot Microbiol 41:569-586

Partensky F, Blanchot J, Vaulot D (1999) Differential distribution and ecology of Prochlorococcus and Synechococcus in oceanic water: a review. Bulletin de l'Institut Océanographique, Monaco (Special) 19:457-475

Petz W, Foissner W (1992) Morphology and morphogenesis of Strobilidium caudatum (Fromentel), Meseres corlissi N.Sp., Halteria grandinella (Müller), and Strombidium rehwaldi N.Sp. and a proposed phylogenetic system for oligotrich ciliates (Protozoa, Ciliophora). J Protozool 39: 159-176

> Pitta P, Giannakourou A (2000) Planktonic ciliates in the oligotrophic Eastern Mediterranean: vertical, spatial distribution and mixotrophy. Mar Ecol Prog Ser 194:269-282 Pitta P, Giannakourou A, Christaki U (2001) Planktonic cili- 
ates in the oligotrophic Mediterranean Sea: longitudinal trends of standing stocks, distributions and analysis of food vacuole contents. Aquat Microb Ecol 24:297-311

Putt M, Stoecker DK (1989) An experimentally determined carbon:volume ratio for marine 'oligotrichous' ciliates from estuarine and coastal waters. Limnol Oceanogr 34: 1097-1103

Reckermann M, Veldhuis MJW (1997) Trophic interactions between picophytoplankton and micro- and nanozooplankton in the western Arabian Sea during the NE monsoon 1993. Aquat Microb Ecol 12:263-273

Revelante N, Gilmartin M (1990) Vertical water column resource partitioning by a ciliated protozoan population under stratified conditions in the northern Adriatic. J Plankton Res 12:89-107

Sanders RW, Caron DA, Berninger UG (1992) Relationship between bacteria and heterotrophic nanoplankton in marine and fresh waters: an inter-ecosystem comparison. Mar Ecol Prog Ser 86:1-14

Skibbe O (1994) An improved quantitative protagol stain for ciliates and other planktonic protists. Arch Hydrobiol 130:339-347

Skovgaard A, Legrand C (2005) Observations of live specimens of Pseudotontonia cornuta (Ciliophora: Oligotrichida) reveals new distinctive characters. J Mar Biol Assoc UK 85:783-786

Editorial responsibility: Urania Christaki, Wimereux, France
Sommer U, Berninger UG, Böttger-Schnack R, Cornils A and others (2002) Grazing during early spring in the Gulf of Aqaba and the northern Red Sea. Mar Ecol Prog Ser 239:251-261

Stoecker DK, Taniguchi A, Michaels AE (1989) Abundance of autotrophic, mixotrophic and heterotrophic planktonic ciliates in shelf and slope waters. Mar Ecol Prog Ser 50:241-254

Strom SL, Postel JR, Booth BC (1993) Abundance, variability, and potential grazing impact of planktonic ciliates in the open subarctic Pacific Ocean. Prog Oceanogr 32:185-203

Suzuki K, Song W (2001) A redescription of Tontonia cornuta (Leegaard, 1915) comb. nov., a planktonic oligotrichous ciliate (Ciliophora, Oligotrichia) from the northern Pacific Ocean. Hydrobiologia 457:119-123

Vaqué D, Blough HA, Duarte CM (1997) Dynamics of ciliate abundance, biomass and community composition in an oligotrophic coastal environment (NW Mediterranean). Aquat Microb Ecol 12:71-83

Verity PG, Langdon C (1984) Relationship between lorica volume, carbon, nitrogen, and ATP content of Tintinnids in Narragansett Bay. J Plankton Res 6:859-868

Yahel G, Post AF, Fabricius K, Vaulot D, Genin A (1998) Phytoplankton distribution and grazing near coral reefs. Limnol Oceanogr 43:551-563

Submitted: May 15, 2007; Accepted: July 31, 2008 Proofs received from author(s): October 9, 2008 